\title{
2 Inter-Asian Corridor of Connectivity (1): The Eurasian World - China, Russia, Ukraine and Western Europe
}

\section{Introduction}

This chapter documents and analyses the first of two major corridors of connectivity that shape and inform the forms of Afghan mobility that this book argues constitute a critical aspect of the connections that link different regions of Asian to one another. The corridor explored in the following pages connects commercial nodes in post-Soviet Eurasia to China via the Muslim-majority states of Central Asia. The chapter's overarching aim is to describe and analyse the contours and structure of the networks that operate along this Eurasian corridor of connectivity, as well as the role played by nodes in the functioning and dynamics of these networks. Recalling Zia's comparison of Afghan traders to Asia's heart, trading networks can be thought of as being the connective tissues that bind different parts of Asia to one another; corridors, in turn, function as conductive tissues that channel and protect traders moving within and along networks. A further way of conceptualising the concept is in terms of a 'pathway', which has been developed by Martin Saxer to describe

a configuration that is at once geographical and social. A pathway is thus not just another word for trade route ... Life along a pathway is shaped by things, stories, rumors, and people passing through - by motion, or by flows, if you will. However, a pathway is neither just another word for flow. While shaped by motion, pathways are also conditioned by terrain, infrastructure and environmental factors like climate and weather. ${ }^{1}$

Work by historians of trading networks has shown how exploring in detail a network's social make up and geographical contours adds to our understanding of the multidimensionality of this type of social formation. ${ }^{2}$ A network may, for example, comprise a single and coherent network; alternatively, a multiplicity of micro-networks connected to one another may make it impossible to identify a single network. Similarly, if the activities of specific networks revolve around a single defining node,

\footnotetext{
${ }^{1}$ See Saxer 2016: 105. ${ }^{2}$ Notably, Aslanian 2014: 14-15, Can 2020, Trivellato 2009.
} 
then, for others, multiple nodes may be of simultaneous significance, with each node playing a specific role in the functioning of a network as a whole. The different roles played by nodes in a network may include, for example, those related to commerce and the centralisation of capital, as well as ensuring the sociological and cultural reproduction of networks by way of provisions for family life and the transmission of knowledge, values and ideologies that lend coherence to the activities and identities of the people making up a network. Historians have also argued that the structure of trading networks plays a significant role in shaping the collective ability of this type of social formation to withstand shocks affecting the commercial and political environments in which they operate. A trading network organised in relation to a single node, for instance, may be especially vulnerable to economic and political transformations and ruptures, whereas one organised in relation to multiple nodes significant sites for networks of capital, merchants, family life, commodities, and information - may be better positioned to adapt and respond to such shocks.

This chapter engages with this body of literature and seeks to answer a series of related questions that primarily address issues concerning the durability of trading networks across space and time. What forms does the structure of trading networks take? How do their structures affect or not affect their durability over the longue durée? Is it accurate to identify commercial networks in the singular, or is it possible to think of multiple networks acting independently but coalescing with one another in relationship to shared goals and ambitions? If nodes are sites at which networks converge and interact, then do commercial networks differ from one another in terms of the number of such nodes that are important for them? Furthermore, do such nodes combine key functions (e.g. economic, sociological, cultural and ideological), or do particular nodes perform distinct roles?

The chapter also seeks to contribute to this body of literature, however, by bringing closer attention to the ways in which the structure of trading networks and the role that nodes play within these are shaped by the wider geopolitical contexts in which they emerge, evolve and operate. The networks discussed in this chapter emerged in the context of the collapse of the Soviet Union, an event that had a range of consequences for the region's dynamics. ${ }^{3}$ At the same time, as I argue across the book, traders' activities are situated at the interface of multiple geopolitical dynamics active across space and time. It is impossible to understand contemporary trading networks along the Eurasian corridor of connectivity, then,

\footnotetext{
${ }^{3}$ See Humphrey 2002.
} 
without also taking into account Russia's and Britain's imperial legacy in Central Asia, as well as the changing nature of Chinese policy towards its western neighbours. These intersecting geopolitical dynamics have all played a critical role in shaping the geography, history and composition of the trading networks discussed in what follows.

By focusing on the geopolitical contexts shaping the activities and identities of an Afghan trading network, this chapter and the one that follows depart from a general tendency in the literature on trading networks of varying types comprising Muslims to dwell on religion's significance in determining a network's distinctive character. A great deal of work across the fields of history and anthropology has sought to explore intersections of religion and economic life, especially in Muslim contexts and trading communities. Most notably, Green has theorised the 'religious market' in a range of settings in the nineteenth-century imperial world as a space in which religious organisations acted as 'firms' and their leaders as 'entrepreneurs'. ${ }^{4}$ In anthropology, many scholars have documented and theorised connections between 'neo-liberalism' and Islam, especially with regard to so-called 'neoliberal piety', often conceived as a manner of being Muslim that brings together Islamic ethics with an emphasis on individual entrepreneurialism and accountability. ${ }^{5}$ In light of dominant trends in the literature on Muslim commercial networks, a surprising conclusion of this chapter is that the identities of Afghan traders working along the Eurasian corridor of connectivity largely revolve around the enactment of secular forms of national identity as much as a public commitment to Islam. Indeed, many of the traders are openly ambiguous about Islam's relevance to their commercial activities and daily lives. The chapter explains this not as evidence of Islam or religion in general being inconsequential to these traders' worldviews. Nor does it argue that the identities of Afghan traders in the Eurasian corridor are simply a legacy of their having been politically invested in socialist forms of ideology during the Soviet period. Rather, it seeks to understand the traders' predilection for the display of secular forms of national identity as being a specific facet of the modes in which they navigate between the competing Eurasian geopolitical projects that shape the contexts in which they live their lives and earn a livelihood. Geopolitical projects initiated by Russia and China are of greatest significance to the contexts inhabited by the traders acting in the Eurasian corridor.

\footnotetext{
${ }^{4}$ Green 2011 and Green 2014.

${ }^{5}$ See, for example, Atia 2013. For a critical discussion, see Osella and Osella 2009.
} 
Analysing the structure of trading networks also raises important questions about the relationship between this type of social formation and the geopolitical contexts they navigate. On the one hand, the geopolitical ambitions of multiple nation states directly affect the lives and activities of the traders explored in this chapter. On the other hand, nation states also seek to instrumentally use the trading networks and communities operating across their territories as a means of expanding their reach and influence geopolitically. In what follows, for example, I document the role played by Afghan traders in the organisation of meetings between Taliban and Afghan politicians in Moscow; in Chapter 4, we see how in the Chinese city of Yiwu traders are also deployed in attempts to brand the city as a tolerant commercial hub on the 'Silk Road'.

Better understanding the relationship between trading networks, the nation states in which they operate and the dynamics of various geopolitical projects can have important implications for the foreign policies of weaker countries squeezed between more powerful neighbours. Afghanistan has for long been nestled between powers seeking to extend their influence and reach beyond imperial and national boundaries and in a manner that has sought to limit the country's ability to act autonomously on the global stage through foreign policy and diplomacy. A strong case exists for treating Central Asia's transnational actors as 'everyday diplomats' - a term that emphasises the capacities that particular groups and networks of persons have in the skills of diplomacy, especially those of negotiation and cultural/linguistic versatility. But what might recognition of the everyday or informal diplomatic skills of the mobile citizenry of small nation states mean for specific countries? ${ }^{6}$ Nation states in many regions have increasingly recognised how the diplomatic skills that sections of their populations have acquired over the course of decades of transregional mobility can add a new layer to their foreign policy agendas and the practices they deploy to form interstate relations. ${ }^{7}$ Afghanistan could similarly capitalise on the navigational agency that its traders employ along multiple human-commercial corridors. Yet, in order to do so, one-sided stereotypes that circulate about traders from the region need to be rigorously contested. Traders navigate complex geopolitical dynamics in sophisticated and nuanced ways. A recognition of such forms of navigational agency stands to increase the likelihood of Afghanistan and similarly positioned countries developing the role that traders and trading networks play in informal diplomacy. More generally, trading networks bring attention to the geographies,

\footnotetext{
${ }^{6}$ Marsden, Ibañez-Tirado and Henig 2016. ${ }^{7}$ Christelow 2012, Yolaçan 2019a.
} 
activities, skills and cultural as well as linguistic aptitudes of people, rather than those projected upon them by nation states. ${ }^{8}$

\section{Trading Networks: Structures, Dynamics and Geographies}

Historians working on long-distance trade have identified two especially significant types of trading network: monocentric and polycentric networks. In his study of the Armenian merchant community of New Julfa, Aslanian argues that Armenians constituted a 'multinodal monocentric network'. Multiple nodes were critical to the activities of New Julfa's Armenians: both the objects and credit necessary for commerce and the women and priests central to the network's social and cultural reproduction, however, had their origins in New Julfa. In this sense, New Julfa formed a single dominant 'nodal center' that 'defines and regulates the identity and economic vitality of the network as a whole'. ${ }^{9}$ By contrast, 'multinodal polycentric' trading networks are identified through their having no single 'nodal center that dominated most aspects of ... the lives of merchants and members of the same community'. ${ }^{10}$ Multinodal polycentric networks, by contrast, operated from numerous centres, each of which was of if not equal then varying importance for the activities of the trading network as whole. ${ }^{11}$

Differences in the structure of historic trading networks had significant implications for the types of commercial ventures embarked upon by the traders. Mononodal networks privileged partnerships with individuals internal to their network. Traders active across polycentric networks regularly developed relationships with individuals external to the network they formed; doing so was essential to the expansion of networks into new contexts - a key principle upon which the durability of such networks was premised. ${ }^{12}$

Historians have also suggested that a network's multinodal or mononodal nature also had implications for its ability to withstand transformation in the contexts across which it operated. Aslanian focuses on the decline of Armenian trading networks in the wake of the calamity that beset its central node of New Julfa after Nadir Shah's invasion of the city in the mid-eighteenth century. The commercial activities of the networks were connected to the city to such a degree that they were unable to survive in the aftermath of its sacking. Aslanian's work also illustrates, however, that a network's durability is not merely determined by its

\footnotetext{
${ }^{8}$ Cf. Pickett 2015, Yolaçan 2019a. $\quad{ }^{9}$ Aslanian 2014: 14-15. ${ }^{10}$ Ibid.

11 See Trivellato $2011 .{ }^{12}$ Markovits 2000.
} 
mononodal or multinodal structure. Durability, rather, is also conferred by a network's ability to switch between and connect different fields of agency, for example, those of economics and politics. Thus, if New Julfa's Armenians' collective commercial activities suffered irrevocably in the wake of the decline of their central node, merchants subsequently played a major role in creating new forms of political identity and institutions: they reinvented themselves as members of an Armenian nation and called for the creation of a nation state. ${ }^{13}$ In this sense, networks also switch between different fields of agency, and doing so can ensure their longterm relevance and influence in changing political and economic circumstances.

\section{Students, Merchants, Workers and Sellers: Eurasia's Afghans - An Overview}

One regional context in which Afghan traders have been especially adept operators is that of the countries of the former Soviet Union. Given that Afghan networks operating in these contexts pivot between commercial nodes in China, and often extend into cities in Western Europe, I refer to them as operating within a Eurasian corridor of connectivity.

Afghan traders themselves analyse, reflect upon and clearly articulate the role they have played in establishing commercial routes between China and the countries of the former Soviet Union. During the course of my fieldwork, traders working in the Eurasian corridor of connectivity would often remark to one another that 'we Afghans have made a name for ourselves as traders in the markets of Russia and Ukraine'. Similarly, one evening in Yiwu over a dinner in an Afghan restaurant, a St Petersburg-based trader gave me a finely argued account and analysis of the ways in which Afghans had come to be established merchants in Russia and Ukraine. In this sense, Afghans are not only the authors of trading routes and geographies but, importantly, they also recognise that they are, and this, in turn, feeds into their distinctive sense of themselves as actors affected by but also influential in geopolitical projects and processes.

However, officials from the region and beyond often view mobile Afghans in Central Asia as either costly refugees or terrorists/criminals. ${ }^{14}$ Since 2001, policy relating to Afghan traders has been confused. States in the region, such as Turkmenistan, have introduced policies that specifically target the commercial activities of Afghan traders. ${ }^{15}$ Less frequently,

13 Aslanian 2014: 214. ${ }^{14}$ UNODC 2012.

15 For a detailed account of the effect of Turkmenistan's policies on Afghan traders, see Chapter 2 in Marsden 2016: 118. 
policymakers have encouraged Afghan merchants to invest in the commercial and agricultural sectors of their countries. This was the case in Uzbekistan following the installation in 2016 of Shavkat Mirziyoyev as the country's president, for example.

Afghanistan's long-distance merchants in Eurasia organise their commercial activities in relationship to multiple commercial nodes. The distribution of these nodes reflects the economic geography of particular countries but also the longer history of Afghan migration to the region. The nodes in which Afghans work and have played a key role in establishing markets are often cities and towns in which people from the country had studied and trained during the Soviet period. A handful of such nodes is of particular significance to the collective activities of Afghans across the expansive Eurasian arena: Moscow and Odessa, for example, not only act as suppliers of commodities imported from China for their immediate environs but also at wider national and even international scales - traders in Moscow 'export' goods to Belarus, while those in Odessa are involved in the transport of commodities to Russia. None of these nodes, however, assumes a position of overwhelming importance over other nodes in the network - a point underscored by their simultaneous presence and the ways in which they jostle for position and influence with one another. As I have explored in detail elsewhere, kin- and ethnicity-based relationships help to shape the commercial relationships of Afghan traders. Yet the traders also collectively value the capacity to develop ties to persons external to their networks - such ties regularly take the form of marital bonds to women from the societies in which they live. ${ }^{16}$ Indeed, traders take pride in demonstrating their ability to establish emotional and commercial relationships with people of different backgrounds from their own; traders often also emphasise that their closest friends and commercial confidants are of Russian and Ukrainian rather than Afghan heritage. A trader in his late forties whom I came to know in Odessa, for example, proudly told me that he travels to China to purchase goods with a Ukrainian friend rather than his Afghan associates; such visits, moreover, also often involve holidays in Asian destinations, such as Sanya in China or Thailand's coastal resorts. In these ways, the activities, identities and geographical distribution of Eurasia's Afghans point towards the network's multinodal nature.

Afghan traders' interactions with politics and the state are also comparable in particular respects, however, to those of New Julfa's Armenians. Afghan traders currently active in the former Soviet Union mostly embarked upon their careers as officials in the pro-Soviet Kabul-based

${ }^{16}$ See Marsden and Ibañez-Tirado 2015. 
government. They formed a political grouping that lost authority in 1992 over what had been its political centre (Kabul) as well as of Afghanistan's state institutions more generally. In the wake of these losses, relationships cultivated in the field of politics remerged in the form of an economic network. Having undergone higher education and training in the Soviet Union, the individuals making up the network were intimately familiar in multiple respects with formerly Soviet Eurasia. ${ }^{17}$ After 1992, thousands of mid-ranking government officials and army officers moved from Afghanistan to the cities in which they had studied in the former Soviet Union, including Moscow, St Petersburg, Kharkiv, Dushanbe, Odessa and Minsk. These cities had played an affective and ideological role in the life trajectories of Afghans: they were centres of professional training and education, and places in which young Afghan men had matured and come of age. The experience of coming of age in Soviet contexts had resulted in many Afghans marrying local women they met during their years as students and officials. After returning to the former Soviet countries after the collapse of the government for which they served in Kabul in 1992, they began to earn a living and generate capital through trading in the informal markets and bazaars that had surfaced across the former Soviet space in the context of the collapse of the command economy. A range of diaspora organisations - including those run by Afghans as well as other communities such as Vietnamese - played a critical role in establishing these institutions. ${ }^{18}$

Soviet-sympathising Afghans who studied in Soviet universities, technical institutes, boarding schools and orphanages (internat) and party schools during the 1970s and 1980s played a critical and pioneering role in establishing Afghan commercial activities and networks in the post-Soviet space. ${ }^{19}$ These students engaged in petty trade on the side of their studies. They dealt in foreign currency and clandestinely sold Indian-made cloth and jeans from Hong Kong to Soviet citizens. On home visits to Afghanistan, they transported air conditioning units made in Azerbaijan as well as Russian-made teapots. The goods they brought to Afghanistan from the Soviet Union also found their way to Pakistan along established smuggling networks. At the same time, Afghans visiting India also brought items of wooden handicraft back to Kabul, and these were subsequently taken for sale in Soviet cities. During the Soviet era, then, Afghan students became sophisticated actors in the

${ }^{17}$ Ibañez-Tirado 2019. $\quad{ }^{18}$ Humphrey 2002 and Marouda 2020. See also Spector 2017.

${ }^{19}$ On the history of Afghan-Soviet educational programmes, see Nunan 2016. For a discussion of the importance of Central Asia to official depictions of Soviet modernity in Africa and Asia, see Kalynovsky 2013. 
field of informal international trade and, in the course of doing so, helped to author a series of intersecting trade routes on an inter-Asian scale.

Afghans who attended different types of institutes and training centres in the former Soviet Union remain active in trade in Russia and Ukraine today. The specific nature of their early experiences in the Soviet Union, however, is held by them to have had long-term implications for their lives and livelihoods. Traders often remark that the most successful Afghans working in these contexts are from among the last batch of students sent from Afghanistan to the Soviet Union. It is often said that this generation of students was unencumbered by the prospect of having to return to work for the state in Afghanistan; in the wake of the Soviet collapse, rather than studying, they immediately set to the task of making a living through trade: it is this final cohort of students to the Soviet Union that went on to establish the most sizeable businesses. By contrast, Afghans who were enrolled by participation in interstate Afghan-Soviet programmes as primary school goers in Soviet boarding schools are regarded as having faced the most difficulties earning a livelihood. Having been regularly sent for education in boarding schools in the wake of losing fathers or close relatives in the Soviet-mujahidin conflict in Afghanistan, they lacked the moral and financial support available to students who travelled for education on bursaries. ${ }^{20}$ Moreover, the upbringing (tarbiya) of Afghan children in boarding schools is also said to have distanced them from 'Afghan culture and traditions' (urf-o adat-e afghanha) - this is something, the traders argue, that made it harder for them in future years to establish successful relationships of trust with their compatriots on which the conduct of informal commerce depends. Indeed, several of these 'internat boys' are said to have turned to crime and violence in the tumultuous years following the Soviet collapse. In these ways, the transition of Afghan networks from those based on politics and ideology to trade and commerce was gradual and layered; differently positioned groups of actors had varied and diverse experiences of life in the interstices of Afghanistan and the Soviet Union and adapted to changing scenarios in a multiplicity of ways.

The trading activities of these Afghan students built on a deeper knowledge of the historical trade in Muslim Central Asia and Eurasia. Various Afghan networks - including those made up of Sikhs and Hindus, as we will discuss in greater detail in Chapter 2 - were active in the nineteenth

${ }^{20}$ On this Soviet programme and the role played by the transnational transfer of children from Afghanistan by both the USSR and the United States during the Cold War conflict in the 1980s, see Nunan 2016: 229-33. 
century in the trade between British India and Central Asia/the Russian Empire, stretching to Murmansk, close to the Arctic Circle. ${ }^{21}$

After the collapse of the Soviet Union in 1991, Afghan traders helped ensure that the populations of its successor states received basic foodstuffs. They imported and re-exported to Central Asia foodstuffs imported from Iran and Pakistan. In the same years, they also established themselves in the wholesale market in Chinese commodities in Russia, Ukraine and Belarus. Doing so involved establishing trade routes between China and the post-Soviet countries, interacting with officials and negotiating market access with other influential trading communities. Initially, Afghans involved in such forms of trade travelled to China from the formerly Soviet cities in which they lived. They purchased commodities before arranging the transport of these themselves to the markets in which they worked. A trader aged in his early seventies who is currently based in Odessa told me of the long train journeys he made in the 1990s from Moscow to China, travelling by way of Almaty and purchasing goods in Urumqi, Harbin and Beijing. On their return visits, the traders often met the trucks that transported the Chinese commodities they had purchased at several national borders. My interlocutor in Odessa told me that he needed to do this to arrange the payment of bribes (rishwat) to customs officials, thereby hastening the arrival of the goods at the markets in which they conducted business.

Traders not only built pragmatic and cooperative relationships across the expansive Eurasian arena. A trader in his late fifties who lives in Yiwu and imports food products from Ukraine to China and also runs a business in one of Moscow's wholesale markets told me that in the 'early days' of China-Russia trade, Afghans also had arrangements with the transport companies that were influential in the formerly Soviet countries. He emphasised in particular arrangements between Afghan commodity traders and a transport company run by a wealthy Azeri businessman. ${ }^{22}$ The trader remarked to me that 'we Afghans played a big role in starting the trade between China and Russia, but we also had to work with different groups of people in order to do so'. So, if the trading networks along which goods and commercial personnel moved were characterised by their Afghan identities, the corridors along which they operated and that supported, protected and channelled their activities arose out of commercial exchanges and interpersonal relationships with people from a range of ethnolinguistic and national backgrounds. For the traders, the ability to negotiate arrangements with companies run by renowned individuals and operating on a Eurasian scale is regarded as

21 Dale 2002. $\quad 22$ On Azeri traders, see Yolacan 2018. 
further evidence of the context for their agency being geopolitical in scope rather than narrowly national.

After the US-led invasion of Afghanistan in 2001, circulatory migration between the country and former Soviet settings continued: individuals and families fleeing the conflict between the international forces and the Taliban officially registered themselves in post-Soviet countries as refugees. At the same time, wealthier families also moved to the former Soviet countries, including those with established businesses in the country and others who had worked as translators for the international forces in Afghanistan; such migrants regularly put their savings into businesses established by longer-term residents in the region. ${ }^{23}$ The interconnections between the movement of traders and refugees and migrants are of critical importance to the dynamics of Afghan commercial networks in the post-Soviet world - an issue to which I turn in Chapter 6. Government policies in formerly Soviet countries, as well as the activities of international institutions such as UNHRC and the ILO, shaped and influenced migratory movements. Yet the routes upon which the migrants travelled and the settings in which they stayed bore the imprint and agency of Afghans themselves. Afghan traders in Russia and China have reported to me how during the 1990s and early 2000s they established relationships with officials ranging from border officials to those working on regional railway systems that allowed them to 'facilitate' the movement of migrants from Afghanistan to a range of settings across the former Soviet Union. Men who embarked upon such journeys have told me that 'smugglers' (qachaqbar) oversaw the routes upon which migrants travelled to Moscow: 'smugglers' arranged for them to board trains at unscheduled stops in remote locations in Central Asia's steppes, for example. As a result of activities such as these, a steady flow of refugees into the Soviet countries from Afghanistan ensured a source of relatively cheap labour for merchants working in these contexts. Refugees and undocumented migrants worked as sellers for the traders, handling day-to-day commercial activities in the wholesale and retail shops they owned.

Established Afghan merchants in post-Soviet countries supported but also profited from the presence of the 'new arrivals' (naw umada). Newcomers to the former Soviet countries also did much of the heavy lifting in the markets, manually moving goods between warehouses and shops and transporting them in vehicles from market to market. In the nodes of the Eurasian corridor, as in the many other contexts in which Afghan traders work, the legal position of such migrants was precarious. ${ }^{24}$ A significant proportion of such migrants did not have the necessary

\footnotetext{
${ }^{23}$ On this type of work in Afghanistan, see Mojaddedi 2019.
}

${ }^{24}$ Reeves 2013. 
documents to live in the countries in which they were based, let alone to work and earn a living for themselves and their families in Afghanistan to whom almost all send money in the form of remittances.

The story of Dil Agha exemplifies many of the themes discussed in this chapter so far. Dil Agha was a mid-ranking state official in the Sovietaligned government of Afghanistan in the 1980s. After the regime's collapse in 1992, he initially moved to a Soviet successor state in the Caucasus, where he worked for a company that sourced hazelnuts for export to Ukraine. In the Caucasus, he married a local woman, and the couple moved to Ukraine with their newly born child. In Ukraine, Dil Agha initially sold goods that he took on a credit basis (qarz) from an established Afghan trader of Hindu background. After four years, he had earned enough credit working in this manner to rent his own shop from the market authorities; he eventually began travelling to China and independently importing children's bicycles to Ukraine from Yiwu. At the time of our first meeting in the summer of 2012, it was clear that his prudence and creditworthiness were reflected both in the capital he had earned over the years and his reputation in the bazaar as a trustworthy person.

As the years passed, Dil Agha made enough profit to buy the shops (shipping containers) in which he sold his goods; he was later also able to purchase warehouse space (gudam; anbar) in a building close to the market. He then bought shops next to his own in order to prevent his competitors from doing so and weakening his business. As we shall see in greater detail in Chapter 6, Dil Agha was also supported in his business activities by 'newcomers' from Afghanistan: his nephew (barodarzada, brother's son) migrated to Ukraine by way of an informal route in 2014 and worked for two years alongside Dil Agha in his shop and warehouse. Dil Agha also held the money of a transient Afghan in Odessa for safekeeping, using it to buy the commodities in which he dealt. By 2015, Dil Agha was comfortable in terms of the living standards of Afghan traders in Odessa but by no means regarded by the community as 'rich' (puldar). In addition to three containers and a warehouse, he also owned a renovated Soviet-era flat, as well as a smaller two-bedroom apartment in a newly built residential complex. Despite being able to successfully accumulate and invest capital over twenty years in Odessa, the decline in the value of Ukraine's currency in the wake of Russia's annexation of Crimea in 2014, alongside increasing levels of cut-throat competition between traders from Afghanistan in the market, meant that Dil Agha was always seeking to cut his daily costs.

Dil Agha was widely held in high esteem by other Afghan traders based in Odessa, and much of his social life revolved around personal 
relationships with such traders, as well as in his participation in community organisations of the type I discuss later in the chapter. Yet competition in the market in Odessa is also a powerful aspect of the traders' lives, and a consideration of Dil Agha's relationships with his compatriots reveals that while trust plays a critical role in the traders' modes of making a living, it is over-simplistic to assume that it is the fundamental tissue that binds trading networks together. According to Dil Agha, an Afghan who had lived in Canada for many years had moved with his family to Ukraine in the mid-2000s. This incomer had started a business selling children's bicycles. His business was substantial: he imported scooters from China bearing his own company's logo, meaning that he had entered into a contract (qaradad) with a supplier to buy a specified number of products each year. Indeed, this trader also exported the branded scooters from China to Russia, where he owned warehouses and shops in markets in $\mathrm{St}$ Petersburg and Moscow. Furthermore, the trader's brother had recently migrated to Odessa from London, bringing with him savings generated from working in the city initially as a waiter and subsequently as a taxi driver - these were also invested in the brother's scooter business. For Dil Agha, the two brothers were attempting to dominate and control Odessa's market in scooters. Yet attempting to do this by using money transferred from London and Canada was unjust (beinsaf) for Afghan traders who had spent years building up a business in the SeventhKilometre Market.

Competition was not only cut-throat in the market due to rivals from beyond what Dil Agha and others regarded as being the moral community of Odessa's established Afghan traders. Dil Agha told me that his business had suffered on several occasions due to the skulduggery of his own Afghan friends. Dil Agha is part of a circle of friends who all identify as being from northern Afghanistan; the men making up the circle are roughly of the same age and political background. The friends socialise in all-male group gatherings, as well as together with their families; indeed, they have exchanged daughters and sons in marriage with one another and their wider kinship networks as well.

The four men refer to their friendship circle as constituting a kolektif. One of the friends in the kolektif is Hajij Karim, a trader from an ethnically Uzbek family in northern Afghanistan who had studied in a military institute in Ukraine in the early 1980s and served in the Afghan army until the collapse of the regime in 1992. Dil Agha told me how two years previously Hajji Karim had imported a large number of scooters from Yiwu; at the same time, he had arranged a shipment of the same items for Dil Agha. Having apparently assisted Dil Agha in bringing a larger number of scooters to Ukraine than he would have been otherwise able, Hajji 
Karim went on to sell his proportion of the goods at such a low profit margin that Dil Agha was unable to sell the goods at the rate he needed to in order to make a reasonable return. At the end of the season, Dil Agha ended up with many more scooters in his warehouse than anticipated. After this experience, Dil Agha told me that he stayed clear of Afghans in Yiwu, preferring to pay for the services of Chinese companies to arrange the export of his goods to Ukraine.

\section{Sevastopol Hotel: From Olympic Accommodation to Eurasian Trade}

Transient migrants received, however, a degree of protection from organisations registered by Afghans in the various countries in which they lived. These organisations - often referred to as 'diasporas' in order to comply with legal convention in formerly Soviet countries - acted as an important mechanism through which state officials communicated with the Afghan community through formal and established structures. Influential Afghan traders with close ties to people of power and authority in post-Soviet states established and subsequently directed such diaspora organisations. They enjoyed such relationships mostly because they had served in highlevel government positions during the era of the pro-Soviet Afghan state. The head of one of the most prominent of these organisations in Russia, for instance, served in a high-level position in the pro-Soviet government in Afghanistan's Ministry of Interior in the 1980s. The leaders of these organisations were able to deploy their relationships with the officials of the countries in which they lived in order to safeguard - at least partially the informal commercial activities of Afghan merchants, as well as the ability of undocumented migrants to work in specified markets and trading spaces.

It is helpful - as Anderson has suggested - to think of such organisations and the marketplaces they have played a major role in co-establishing as 'institutions of neighbourhood'. Such institutions are critical in 'fostering durable trade networks' because they 'play a major role in pooling reputation, dispute resolution' and the fashioning of 'shared sensibilities and ... familiarity'. ${ }^{25}$ In terms of the wider arguments of this book, it is these specific social institutions, rather than the trading networks as a whole, that play a critical role in establishing the 'rules of the game' in relationship to which traders work and make a livelihood.

In the context of the Russian Federation, a diaspora organisation that played an especially influential role in securing the commercial success

${ }^{25}$ Anderson forthcoming(b). 
and long-term durability of Afghan trading networks was established in a market complex known as the Watan Trading Centre located in the Sevastopol Hotel. The Sevastopol Hotel was built by the Soviet Union specifically for the 1980 Moscow Olympics. By the mid-1990s, however, two of its buildings had been transformed into the trading offices and wholesale shops of international traders from a range of backgrounds; the traders included Yemenis and Syrians, but the most densely represented group in the buildings identified as Afghan. The Watan Trading Centre is well known among traders from Moscow and across the Russian Federation more generally as a commercial node important for the procurement of commodities of daily use imported from China. Commodities ranging from bags and jewellery to gemstones, beads, hardware and souvenirs are all available for wholesale. The wider environment of the hotel is influenced by the cultural backgrounds of the traders who work in its buildings. Traders from Afghanistan and South Asia are able to buy ingredients for preparing dishes loved in their home countries from a Pakistani-owned shop that imports foodstuffs from Afghanistan, Pakistan and India; there is a restaurant serving Afghan specialities and, at the entrance to the complex, Afghan migrants sell snacks from their home country that they prepare in their apartments.

Afghan traders working in cities across Russia visit the hotel to purchase commodities. Travelling from cities such as Rostov-on-Don, St Petersburg, Kazan, Stavropol and Krasnodar, they purchase (often on credit from traders with whom they have long-term ties) commodities that they then sell on a wholesale basis in the cities in which they run wholesale businesses. The hotel-cum-commercial complex is of importance not only for traders in the Russian Federation but also those working in Ukraine and Belarus. Traders based in Odessa on Ukraine's Black Sea Coast transport goods informally to Moscow by way of the border city of Kharkiv in Ukraine - this form of trade has declined in the wake of the conflict between Russia and Ukraine but is still relevant to the commercial activities of Afghan traders. At the same time, traders based in Moscow also transport the commodities in which they deal with the approximately 200 traders from Afghanistan active in the Belarusian capital, Minsk. Similarly, the commodities imported by Afghans from China to Odessa are sold on a wholesale basis in the Seventh-Kilometre Market, from where they are distributed across Ukraine, as well as to the Russian Federation.

In the early 1990s, many of the traders and undocumented migrants who worked in the Sevastopol Hotel complex lived in what had formerly been guestrooms. Leaders of the officially registered Afghan diaspora association made informal agreements with powerful officials in 
Moscow to secure this arrangement. Afghans who lived in Moscow during this period have reported to me that such agreements reduced the likelihood of Russian security officials and personnel entering the premises of the hotel-cum-market and asking to see the identity papers of unregistered Afghans who laboured within. Indeed, during visits I made to the Sevastopol Hotel in 2012 and again in 2014, I was told that around 4,000 individuals of Afghan origin ran businesses and/or worked in its shops and warehouses. Labourers with whom I spoke remarked that within the confines of the building they largely did not need to worry about being pursued by Russian security personnel. There were, however, occasional breakdowns in such agreements, which intermittently resulted in undocumented labourers being detained and sometimes deported to Afghanistan by the Russian authorities. On a number of occasions, the local authorities had closed the market and seized 'contraband' goods that had not completed formal customs procedures. Such events resulted in a considerable loss of earnings for Afghan merchants, but they were generally resolved after discussions between Russian officials and diaspora leaders had resulted in agreements and financial exchanges.

In the context of Russia, traders and state officials form relationships with one another behind closed doors. As a result, 'diaspora leaders' are able to play a central role in mediating relationships between the state and trading networks. Russian officials recognise such individuals as having the capacity to direct and discipline the behaviour of traders more generally. As Anderson has helpfully pointed out, the conduct of diplomacy entails the 'horizontal' skills of working across linguistic and cultural boundaries, but it is also premised on the 'vertical' skills that enable figures to control and direct the behaviour of those whom they represent. ${ }^{26}$ As we shall see later, formal and informal diaspora organisations in the Sevastopol Hotel and the former Soviet Union more generally play a critical role in securing the durability of networks by ensuring that members maintain at least a degree of compliance with collective practices, standards and expectations.

It is important, however, not to over-amplify the power of diaspora organisations to direct and shape the networks. Nor should we assume that the vertical relationships at the heart of such organisations are automatically or inevitably successful in disciplining networks. In the case of the Sevastopol Hotel, besides the intermittent breakdown in trustful relationships (gosast-e ehtimad) between its officials and those of the

${ }^{26}$ On the role that social institutions and ties to figures of authority play in the disciplining of diasporas and trading networks in the Arab world, see Anderson forthcoming(a). 
Russian state, the Watan Trading Centre is widely criticised by Afghan traders themselves. Traders are often resentful of what they view as being the ways in which holders of authority in the diaspora organisation have benefited from their relationships with state officials, especially in promoting and protecting their own commercial dealings, often to the detriment of the compatriots they proudly claim to serve. Resentment towards the diaspora leaders is often visible in conflicts that erupt within marketplaces between the leadership of community organisations and the traders, mostly over rent rises for shops and warehouses. Traders are positioned differently in inter-network hierarchies, then, and these are evident in their commercial practices and relationships. As we shall see later in the chapter, such hierarchies also manifest themselves in debates over the specific form taken by cultural gatherings. Such tensions not only inform the interpersonal relationships of traders operating in marketplaces such as the Sevastopol Hotel but also contribute to the dynamic geographies of the settings in which they work. Traders who have secured access to Russian citizenship and no longer require the same degree of protection as they had while refugees and migrants, for example, tend to move their businesses into newly established markets rather than those controlled by particular associations. Over time, traders predict that diaspora organisations will hold less sway over their activities, and that this will lead to their decline.

In other contexts in post-Soviet Eurasian settings, Afghan traders are involved in publicly contentious relationships with state officials, which leads them to deploy different strategies to achieve their aims and goals. The Seventh-Kilometre (or Sidmoi) Market in Odessa, Ukraine, for example, is one of the largest informal markets in the former Soviet Union. The traders who sell goods from the thousands of containers that form the basic physical infrastructure of the market hail from a multinational range of backgrounds: Ukrainian and Moldavian merchants work alongside sizeable communities of traders, labourers and money exchange agents from Vietnam, Afghanistan and Turkey. ${ }^{27}$ As with the Sevastopol Hotel market complex, so too in Odessa do the market traders work with the local and national state authorities in a manner that enables them to influence and shape a range of realms that are of critical importance to their livelihoods, most importantly those of taxation and the payment of customs duties and those relating to the presence of undocumented migrants who work as labourers in the market.

27 Skvirskaja 2014. 
Agreements between traders, market authorities and state officials regularly break down, however. In the summer of 2018, for example, traders I knew told me that officials they identified as being from Ukraine's federal custom and taxation department were becoming a noticeable presence in the market. The officials wore forms of identityprotecting clothing (balaclavas) and visited shops, requesting sight of the identity documents of both shopkeepers and their labourers. The officials also reported traders - including those originally from Afghanistan - who employed undocumented migrants in their businesses, as well as Ukrainian nationals not formally registered (for tax purposes) as their employees. During this period, traders kept a careful eye on customers unknown to them who entered their shops; they told me that undercover tax officials and police regularly sought to fine or even extract bribes from shopkeepers by gathering information about them in this manner.

The traders told me that such officials were especially targeting the many Vietnamese money agents working in the Seventh-Kilometre Market. Marina Marouda has documented the important role played by Vietnamese working in the Seventh-Kilometre Market in various forms of currency markets. ${ }^{28}$ At the end of each day, Vietnamese 'money people' change the Ukrainian cash earnings of shopkeepers into US dollars a more stable currency in which traders often maintain their savings and reserves. Vietnamese exchange agents also arrange international US dollar money transfers to China - doing so allows traders in the market to pay their Chinese suppliers in instalments for the commodities they import to Ukraine.

Most of the Afghan traders I know in Odessa deploy the services of Vietnamese money exchange agents to pay their Chinese suppliers. Afghans are active in global currency markets, yet undertaking this type of activity in Ukraine is widely regarded as complex and dangerous Ukrainian authorities are said to regularly arrest Afghans who are involved in such activities, and this has on occasion resulted in their imprisonment. One afternoon while I was sitting in the shop of an Afghan shopkeeper in the market, an Afghan man in his mid-twenties approached us and asked the shopkeeper if he had any money to change from local currency to US dollars; after the shopkeeper had declined the offer and the young exchange agent had left, he remarked to me that the young man was foolish to engage in this activity in Ukraine as it could cause him serious trouble with the authorities. Traders are aware of the sensitivities attached to the different types of commercial activities in which they are involved across the varying contexts in which they work

28 Marouda 2020. 
and use this knowledge to alter their behaviour and strategies on a context-by-context basis.

In the context of Odessa, attempts by Ukrainian officials to further control and limit the activities of Vietnamese money exchange agents in the market had the potential to directly affect Afghan commercial activities in the city: restrictions on the activities of the Vietnamese would make it harder for them to send payments to China and thereby raise the costs of trading with the country. Many Afghan traders in the SeventhKilometre Market with whom I spoke perceived the attacks on the Vietnamese exchange agents in the market as being unjust (beinsaf). They claimed that the driver behind the high level of official interest in the activities of the Vietnamese was not a desire to regulate and formalise the making of financial transactions and the payment of taxes in the market. Rather, they argued, it arose from a need on the part of corrupt Ukrainian officials to gain access to capital in the run up to the country's presidential elections in 2019. As a result, Afghan traders organised among themselves to stage a demonstration in opposition to the behaviour of the state officials in the market. In these demonstrations, they vocally argued that the behaviour of officials entering the market was unlawful because they concealed their identities from the people with whom they interacted. The traders also took active steps to spread news of their demonstration: they contacted a local TV station to cover the events unfolding at the market, for example. A trader in his late forties who runs a successful business in leather products told me that if the city's Afghans were divided internally, they were nevertheless effective at causing a 'ruckus' (ghalmaghal) and resisting the state and its corrupt officials. The ability to organise effectively in order to address changing threats to their mode of making a livelihood is thus an important aspect of the traders' activities in the Eurasian corridor.

\section{Informal Diplomacy}

Relationships between traders and the state are two-way in nature: the officials in the cities and nation states in which traders work see their relationships with Afghan traders as being important in geopolitical terms. In particular circumstances, the region's states do treat these networks as 'instrumental channels' that they and political elites can 'use to achieve their purposes'. ${ }^{29}$ Afghan merchants operating in this expansive context communicate with one another in Farsi and Pashto. But they are always fluent in Central Asia's Turkic and Persian languages,

${ }^{29}$ Anderson forthcoming(a). 
as well as Russian; those who live in China often also speak Mandarin or Cantonese. Authorities in the countries in which they work occasionally seek to instrumentally benefit from the traders' cultural knowledge and adaptability. An Afghan trader in Ukraine was said by his co-nationals in the city to have helped secure the release of a Ukrainian citizen captured by the Taliban in August 2015, for example. In Yiwu, a trader from Afghanistan who operates a company serving Russia and Ukraine as well as Western European countries was elected as representative of the city's approximately 13,000 foreign traders who hail from a wide variety of countries. The trader is now a regular feature at official meetings organised by the city's municipal government and widely featured on China's state television channels. He also plays an active role in an organisation tasked by the city's municipal authorities with resolving disputes between international traders and Chinese suppliers. As I now explore, Afghan traders in Russia have played a major public role in the country's attempts to foster a political settlement between the Afghan government and the Taliban.

Most recently, for example, the Russian authorities have sought to benefit politically and in the field of international politics from their close relationship with Afghan traders based in the country. Against the backdrop of negotiations between the United States and the Taliban relating to attempts to arrive at a political settlement, a conference at a hotel in Moscow run by the Kremlin brought together prominent Afghan politicians and representatives of the Taliban. Official news reports in Russia and in the international media claimed that the event had been organised by an Afghan diaspora organisation in Russia. ${ }^{30}$ The Russian state sought to distance itself from the hosting and organisation of the conference, partly because Afghanistan's government and various international actors in the country were suspicious of the event. Ashraf Ghani, the Afghan president, argued that the conference's delegates were not representatives of Afghanistan and therefore had no capacity to represent the country. Russian officials sought to instrumentally use Afghan traders in the country to extend their influence and reach into a context in which other nation states are playing an active role. At the same time, the willingness of Russian officials to foreground the country's Afghan diaspora organisation in such a manner also illustrates the close relationship Russia has built up with this mobile community over several decades, and the ways in which it regards the traders as being able to play critical if informal diplomatic roles in a fraught geopolitical context.

${ }^{30}$ Roth 2018. 


\section{Traders and Cultural Sensibility}

The remit of the specific social institutions that traders establish is not limited to the strategic making of commercial and political arrangements alone. The traders' social institutions also play a critical role in creating and sustaining the 'shared sensibilities' and 'sense of familiarity' upon which the functioning and durability of trading networks also depend. ${ }^{31}$ During my time conducting fieldwork with Afghan merchants in settings across the Eurasian corridor of connectivity, I came to see the work that traders invested into organising events that enabled the building of such shared sensibilities and forms of familiarity.

On the basis of the earlier description and analysis, the Watan Trading Centre may well come across as a site of hardnosed bargains and the building of pragmatic relationships between traders and state officials. Yet while this is certainly an important aspect of the dynamics of the institution, it is not the only one. In addition to it being the base of several hundred trading companies, the Sevastopol Hotel complex also houses the offices of one of Russia's most influential Afghan diaspora organisations. This organisation mediates between traders and the state; for several years, it also ran an Afghan school to which traders based in Russia were able to send their children for instruction in Farsi, Pashto and Islamic principles. Furthermore, while today traders have easy access to news about Afghanistan from the Internet, in the late 1990s the organisation installed a cable network within the buildings of the hotel that allowed traders to watch TV programmes in Farsi and Pashto in their offices and workspaces. Indeed, the editor of a Farsi newspaper published in the building told me how he wrote news articles about Afghanistan as well as articles on issues relating to Russia's Afghan community. Afghan traders in Russia regularly complain that they are unable to lead public forms of pleasurable social life in the country. A combination of racist attitudes and behaviour from local populations towards 'black-heads' the derogatory term used by some in Russia to refer to Muslims from Central Asia and the Caucasus - and the fear of security officials interrogating them outside of the spaces in which they work leads many traders to avoid spending time with one another and their families in public spaces. The provision of newspapers, schools and television within the trade centre played a critical role in the shared instantiation of cultural values and ideas; this aspect of the activities of traders' institutions also enables collective connections with Afghanistan to be sustained.

31 Anderson 2020. 
Afghan traders in Ukraine have not only established formal diaspora organisations; they are also extremely active and energetic in organising events and gatherings that lay the foundations for building shared sensibilities and forms of familiarity. In Odessa, for example, there are two major types of Afghan community organisations (sazmanha): funds (credit associations) and formal diaspora associations (anjomanha). The funds are institutions led and managed by a committee of Afghan traders who collect financial contributions from Afghans in the market that are used to support traders facing financial difficulties. The committee members of the fund release money, for example, if a trader's business goes into bankruptcy and he loses his source of income. Funds also support traders who need to cover the funeral costs of their relatives in Odessa or travel to Afghanistan unexpectedly, most especially in the case of death and illness in the family. Traders refer to the provision of cash in this manner as billa aywaz - a contribution given on the assumption that repayment is not required. It is expected, however, that if a trader is able to recover his losses that he will return money to those who had pooled together to provide it, but this is not a condition of the support being extended.

Organisations (anjoman) mediate between Afghans in Odessa and the municipal authorities, as well as organising gatherings and events to commemorate important Afghan festivals, including the two Muslim Eid festivals and the Persian New Year (Nowruz) celebrations. Afghan musicians based in Europe are often invited to perform at such celebratory gatherings. A popular London-based singer, for example, performed at a series of concerts organised by an Afghan association in Odessa in 2010. Gatherings such as these ensure that Odessa is a site of significance for Afghan business and cement the city's status as a node in the social and cultural reproduction of transregional networks, meaning that it is known globally as a 'central node of entrepreneurial and affective life' to Afghans. ${ }^{32}$ A further type of event regularly organised in Odessa marks the 'day of martyrdom' (ruz-e shahedat) of political figures from the country, such as former resistance leader and minister of defence Ahmad Shah Massoud (d. 2001). As we shall see in Chapter 4, events such as these are inherently political and often only attended by traders affiliated to particular figures, mostly through ethnolinguistic and regional identity - as a result, they tend to play a role in cementing bonds between micro-networks. Such events mostly involve speeches by traders in Farsi and/or Pashto about leaders' lives and contributions to Afghanistan.

${ }^{32}$ Arsan 2011: 9. 
The close relationships forged by organisations between traders and local authorities invest their activities with political significance. A trader active in one organisation in a Ukrainian city, for example, is said to have built extremely close relationships with local officials and, as a result, is able to support Afghan nationals wishing to enter the country, even if they do not have the necessary documents. The trader is known among traders active within and beyond Ukraine as the 'Minister of Interior' of the country's resident Afghans - a similar figure in another city in Ukraine is said by traders to facilitate the clandestine migration of Afghans from Ukraine to the European Union and is known as the community's 'Minister of Foreign Affairs'. These examples point once again to the extent to which Afghans see themselves not merely as the passive recipients of geopolitical projects but as exerting agency in complex geopolitical contexts. Furthermore, by designating the community as having ersatz ministers of foreign and internal affairs, the traders underscore the extent to which participation in a broad sphere of geopolitics also shapes their collective self-understandings.

Formally established social institutions alone do not play a role in cementing Odessa's significance as a site for the cultural and social reproduction of Afghan trading networks in Eurasia. Afghans also invest considerable effort in the organisation of informal gatherings (majlis) that play a significant role in generating shared sensibilities and senses of familiarity. In the summer of 2016, for example, Riaz - a trader aged in his late fifties in Odessa who had played a widely recognised role in establishing Afghan commercial activities in the Seventh-Kilometre Market - passed away; Afghans in the city knew Riaz for his dedication to business and his prudent approach to doing trade. Riaz was regarded in rather ambiguous ways by Odessa's Afghans. Unlike other traders, he saved his money rather than spending it lavishly on parties and social gatherings arranged for members of the community. At the same time, his purportedly overly distant and miserly natured relationships with his son from his Ukrainian wife was a source of controversy: having never trusted his son with business activities, the boy had grown up with little or no practical sense of business or money. As a result of this problematic relationship, the community feared that the businesses built up by the trader over decades would be 'lost' as there was no one in his family who would be able to manage and run them effectively.

Regardless of his personal shortcomings, the community in Odessa marked the trader's death in as prominent a manner as possible. Members of the community invited me to a gathering held at a restaurant owned and run by an Afghan in the city who also traded in the Seventh-Kilometre Market; I did not attend the funeral itself because 
I was concerned that my presence would detract from the solemnity of the occasion for its attendees, principally because it would lead to further suspicion about why an inglis was interested in the city's Afghans. The pre-funeral social gathering took place in the restaurant shortly before the burial of Riaz's body in the Muslim section of the city's cemetery. Not only were around 100 Afghan traders in Odessa present at the gathering, but it was also attended by men of social and commercial standing from the Afghan community across Ukraine. The representatives of Afghan organisations in Kiev and Kharkiv - both cities with substantial Afghan communities, mostly comprising traders - had travelled overnight by train and car to attend the funeral. The first secretary of the Afghan embassy in Kiev had also travelled from the capital city to attend the event in Odessa, ensuring that it acted as a conduit for relations between the traders and the Afghan government. The traders had also invited wellknown political figures from Afghanistan - these figures had sought exile in Ukraine after the collapse of the pro-Soviet government in Kabul in 1992 and included a former ambassador and a former vice-president from the 1990s. A further individual present at the gathering was a Kiev-based intellectual from Afghanistan. This scholar had studied in Odessa during the Soviet period but instead of turning to trade in 1992 had worked for several years at the Oriental Studies Department of the National Academy of Sciences. Both the former government officials and the intellectual subsist in the country on meagre salaries. As a result, Odessabased traders had supported their visits to the city for the funeral by arranging vehicles to transport them to Odessa, as well as providing them access to Afghan-owned flats in the city. Such provisions ensured that people with access to fewer economic resources than the traders would be able to attend the funeral; as we shall see, the presence of such figures helped to shape the event's significance as a forum for the instantiation of shared cultural sensibilities as well as geopolitical perspectives among the traders.

Much of the conversation at the pre-burial gathering concerned Riaz's life, his successes in the field of trade and the future prospects of his business activities given the specific nature of his family arrangements (in addition to being married to a Ukrainian woman, Riaz also had an Afghan wife with two young children who was also based in Odessa). At the same time, the gathering also formed an opportunity for those present to engage in discussions with one another over a wider range of issues. An issue of particular significance at the time concerned the attitude that traders from Afghanistan held about the conflict between Ukraine and Russia. Many of the traders - a substantial proportion of whom had been aligned with Afghanistan's leftist People's Democratic Party of 
Afghanistan (PDPA) - were hostile towards the Ukrainian leadership's opposition to Russia and desire to forge closer relations with Western Europe and the United States. By contrast, the former vice-president of Afghanistan - who is the author of several books in Farsi on Afghanistan's modern history - forcibly argued the traders should not be so one-sided in their support for Russia and its policies towards Ukraine, not least because they were Ukrainian rather than Russian nationals. Informal gatherings such as these, which involve the deployment of considerable resources by traders - financial, but also in terms of time and personnel provide important fora for the fostering of shared sensibilities and the pooling of knowledge about commercial and political dynamics and developments. Importantly, the funeral gathering also demonstrated that Afghans think in open and reflective ways about the geopolitical dynamics affecting the context in which they lead their lives, and that they also seek to arrive at collective positions on how they should present themselves in relation to such dynamics.

\section{A Mosque or a Discotheque?}

Religion is an important aspect of the organisational activities of Afghans in Eurasia, as well as the personal and collective identities and moral worlds of the community. Islam's role in the dynamics of trading networks, however, is contested, variable, shifting and a source of constant internal debate and reflection. Anthropologists and scholars in related disciplines have tended to invest considerable emphasis on Islam's significance to the coherence of trading networks that comprise people of a Muslim background. ${ }^{33}$ In the context of Eurasia and the Belt and Road Initiative, 'Muslim culture' is also argued to play a critical role in modernday iterations of the Silk Road, allowing Muslim communities across the arena to interact with one another in relation to a shared religious culture. ${ }^{34}$ Literalist forms of Islam are also recognised as playing an increasingly significant role in the Russian Federation in helping to form a distinct culture of 'halal' business. ${ }^{35}$ Religion is an important aspect of the identities and activities of Afghan traders operating along the Eurasian corridor of connectivity but in a far less totalising manner than the earlier accounts might suggest. ${ }^{36}$ Islam's complex role in Afghan

${ }^{33}$ Ho 2006.

${ }^{34}$ Belguidoum and Pliez 2012, Belguidoum and Pliez 2015, Belguidoum and Pliez 2016, Bertoncello, Bredeloup and Pliez 2009, Simpfendorfer 2009.

${ }^{35}$ Benussi 2018.

${ }^{36}$ For a nuanced approach to 'halal exchange' in a different post-social environment, see Henig 2019. 
trading networks serves as an important reminder of the dangers of assuming that mobile Muslims inevitably participate in expressions of 'global Islam'. 37 Afghan traders active in the corridor, rather, actively and consciously distance themselves from expressions of global and reformist Islam and regard doing so as central to their ability to navigate a world of competing geopolitical projects.

Islam's role in the lives of Afghan traders is a source of reflection and analysis by traders themselves. Afghans working in formerly Soviet Eurasian contexts regularly emphasise the extent to which they are more religiously observant Muslims today than during the years in which they studied in Soviet institutes, as well as the period when they first embarked on the life of a trader. Traders often remark to one another that far fewer of their compatriots drink alcohol now in comparison with previous years. Afghans living and working across Eurasia have also established institutions in which they hold and conduct religious rituals and gatherings. ${ }^{38}$ Most regularly, rooms are set aside within markets to act as prayer spaces for Muslim merchants. In Odessa, however, two mosques in the city have been established and are largely attended by Afghans living in the city. Attendance at these mosques reflects the importance of ethnolinguistic diversity in the community: Pashtospeaking traders mostly frequent one, while those from Farsi- and Uzbekspeaking backgrounds tend to attend the second institution for Friday prayers. Two brothers from central Afghanistan who run businesses in Odessa and Kabul established the latter mosque; the congregation of the former has recently purchased a plot of land in a suburb on the city's outskirts upon which they intend to construct a purpose-built mosque. In both mosques, Afghans gather collectively for Friday prayers; they also organise important ritual events, especially feasts held to commemorate the deaths of traders in Odessa and their relatives beyond.

Traders in Odessa comment on the amount of time they spend attending such events, as well as the intensity of the social pressure placed upon them by Afghans to regularly attend Friday prayers and contribute to the organisation of collective religious events. The frequent nature of such events is also a source of consternation because it further reduces the time that traders spend with their families and means they must squeeze important administrative tasks - such as acquiring documents relating to their commercial and family lives - into their already busy lives. Participation in religious rituals and regular practice is, thus, a type of

37 For a detailed consideration of this distinction, see Green 2020.

38 For an analysis of religious institutions established by Muslim migrants in Ukraine, see Yarosh and Brylov 2011. 
activity that plays an important role in forging vertical discipline within the community, as well as in the building of shared sensibilities and intense forms of familiarity upon which the durability of trading networks depends.

Islam plays a stabilising role in Afghan identity and institutions in Eurasia, yet it is also a source of critical discussion. The social and economic resources expended at the city's mosques are in particular a much-commented feature of life among Afghans in the city. It is, however, important not to assume that this aspect of the institutional dynamics of Afghan traders in Eurasia points in any one-dimensional way either to Islam being the central aspect of the traders' identities or to traders identifying with a singular form of Islam. Indeed, the religious institutions established by Afghans in Odessa are not necessarily 'Islamic' in any simple sense. A well-known trader in the city from northern Afghanistan, for example, used a considerable sum of his own money to purchase land close to the Seventh-Kilometre Market on which he built a large three-storey building, ostensibly, at least, for benefit of the community. The building's ground floor is a large mosque, and on its second floor an airy hall is decorated with wall paintings of important figures and landmarks from Afghan history, including King Mohammad Zahir Shah (1914-2007), who was deposed in a coup d'etat in 1973; the Ghurid-era Minaret of Jam; and the Herati-born Turkic poet Ali Sher Navoi (14411501). The latter painting indicates the owner's ethnic Uzbek identity and was a source of criticism among Odessa's Afghans who identify as Pashtun and reportedly told the trader that a building decorated in such a partisan way could not act as the community's collective cultural centre. On the third floor is a 'hotel' comprising a series of rooms that are available for rent for members of the community and guests attending events. The trader told me that he had hoped to profit from the building by renting it to Afghans for the organisation of weddings. Its distance from the city, however, meant that the enterprise failed only a few years after it had been launched. Furthermore, traders in the market who identify as religious (mazhabi; dindar) objected that the structure contained both a room for parties - at which alcohol was inevitably served and a mosque. Indeed, on the occasion the owner invited me to visit the building, my hosts emphasised the importance of seeing the mosque before celebrations got underway upstairs. A trader in his late forties who lives in Odessa remarked to me wilily, 'People couldn't work out whether it was a mosque or whether it was a discotheque.' The culturally heterogeneous building illustrates the complex position occupied by Islam in the traders' cultural worlds, while the debates about it also show how far Islam is a contested aspect of their collective identities. 
Conversations with traders often suggest that the significance of participating in collective forms of Islamic ritual practice lies more in its importance to the display of success in trade than the instantiation of piety. When I asked an Odessa-based trader in his late forties why Afghans did not attend Friday prayers in the city's central mosque, he remarked that it did not have a car park large enough for Afghans to display their vehicles to one another. 'We are more interested in showing how successful we are then attending the mosque', he said. Public forms of sociability are also central to cultural and ideological reproduction over time, however.

More broadly, Afghan traders reflect openly on the functional role they see mosque attendance as playing in the community. Many remark that they regard mosque attendance as important because it demonstrates a trader's social commitment to the community and its networks rather than his attempts to lead a life guided by a particular set of ethical principles. In this respect, many if not all of the traders I know consciously distinguish themselves from Muslims of different cultural backgrounds who identify with 'reformist' forms of Islam and Muslim identity. During research in Odessa in the summer of 2017, for instance, my friends expressed their hostility to what they identified as religious families from Uzbekistan who were active in the promotion of Salafi Islam. Several traders remarked to me that the unwillingness of the Ukrainian authorities to take action against such migrants demonstrated the malaise of the country's security institutions in the post-Soviet period. They publicly advocated for more not less policing of Muslim identities and activities in the country.

A group of traders I know in Odessa - who are closely related to one another through intermarriages conducted since their migration to Ukraine and are involved in shared commercial activities - reflect the complex role played by Islamic practice and belief in trading networks in former Soviet settings. They would always make sure to attend Friday prayers in the mosque in Odessa that had been established by two Afghan merchants. In conversations among themselves, however, the friends who referred to themselves as forming a kolektif - would emphasise that they attended the mosque above all because of social pressure: the consequences of not attending Friday prayers would involve their compatriots commenting on their absence from this most important of weekly ritual events. Indeed, one of the men in the group - a trader in his early fifties from Kabul - proudly remarked to his friends at a family dinner in a Ukrainian fish restaurant that he always went to Friday prayers in the mosque even if he had been out dancing in Odessa's famous nightclubs until early on Friday morning. Another trader - in his late fifties and from 
northern Afghanistan - told the gathering that he encouraged young Afghans to attend Friday prayers because it was shameful to see halfasleep Arab students in the city making the effort to attend the gathering after a hard night of drinking and for Afghan youth to be absent. 'Even if you've been partying until six in the morning', he remarked, 'we should always show up at the mosque on Friday.'

\section{Conclusion}

Before turning to the next Afghan network under consideration, let us briefly recap the arguments advanced in this chapter. First, the chapter has emphasised the prominent and visible role played by traders of Afghan background in formerly Soviet Eurasian settings, illustrating that the history of these communities and the networks they form lies in Cold War geopolitical dynamics while also showing how traders have successfully negotiated the evolving geopolitical projects of countries such as Russia, Ukraine and China. Second, the chapter has brought attention to the importance of specific social institutions built by the traders to their collective activities. It has paid particular attention to the important role that institutions including diaspora organisations and markets play in mediating traders' relationships with state officials, as well as their significance in building shared senses of sensibility and intense forms of familiarity within networks. Third, a distinct but related finding of the chapter concerns the extent to which such institutions in formerly Soviet Eurasian contexts are regularly defined in terms of the shared national backgrounds of Afghans, and it is on this basis that states within Eurasia interact and engage within them. Religion plays a powerful and important role in traders' daily lives and self-identities, yet it is also subtly enfolded within Afghan national identity, something illustrated in the dual role played by mosques as sites of worship but also of the fostering of distinctly Afghan cultural sensibilities, knowledge and identities. To a large degree, indeed, collective Afghan identity is built and performed in relationship to a secular-national identity that is often in competition with the national and religious identity formations of Muslims from different cultural backgrounds.

Traders, then, deploy various forms of civic activism to assert the autonomy of the spaces they have helped to fashion. They also demonstrate their ability to build forms of solidarity with commercial personnel from backgrounds different from their own. Traders actively seek to reject the association of Afghanistan with radical Islam. They largely lead secular lives in which the shared ideal of 'living well' is achieved through the demonstration of commercial success and participation in public forms of 
entertainment. This personal ethics of the good life interact in creative ways with a strong collective and cultural commitment to Afghan national identity. Policies towards migrants in the post-Soviet states reinforce this aspect of the traders' identities: state officials monitor, fashion ties with and channel available support to 'migrant communities' through formally established 'diaspora associations'. The 'corridor of connectivity' that connects China to West Asia on which I focus in Chapter 3 requires traders to fashion identities and social institutions in more unambiguous terms in relation to the Islamic tradition than those explored in the preceding pages. 